\title{
Security of Energy Supply in the New Europe: A Role for the European Atomic Energy Community in the European Union's Neighbourhood Policy?
}

\author{
Pamela M. Barnes
}

\begin{abstract}
External energy relations are essential components of both the European Union's search for an overall energy strategy, an Energy Policy for Europe (EPE) and the development of the European Neighbourhood Policy (ENP). In this article questions are posed about the role for the use of nuclear technology as the means of meeting some of the objectives of both areas of policy. As both the EPE and the ENP are dependent on the negotiation of international agreements with third parties for their effectiveness the focus of analysis presented will be on the EU's legal and constitutional framework for action and in particular the EURATOM Treaty which established the European Atomic Energy Community in 1957.
\end{abstract}

THE EUROPEAN UNION (EU)'S EUROPEAN NEIGHBOURHOOD POLICY (ENP) WAS LAUNCHED by the European Commission in March 2003 (CEC 2003b) and followed by the formal adoption of a Strategy Paper in May 2004 (CEC 2004a). The objective of the Neighbourhood Policy was to achieve a framework for partnership and co-operation amongst states in the arc of instability on its eastern, south-eastern and southern peripheries. ${ }^{1}$ Through the opening of access to the EU's Internal Market and increased economic co-operation it was hoped to promote security, stability and prosperity in the wider European region. For some of these states in the eastern region (especially for Ukraine, Georgia, and Moldova and to a lesser degree for Armenia) there is an ambition to eventually accede to the EU. Acceptance that this ambition is unlikely to be achieved in the short to medium term has increased the support for the development of the ENP in the Eastern European states.

Accession is not the objective of the bilateral agreements being established under the umbrella of ENP policy between the EU and the ENP states. The agreements are however framed as a result of the experience the EU has in the use of conditionality in the 2004/7 accession process. The 'Country Strategies' for each of the ENP states outline conditions for

\footnotetext{
${ }^{1}$ The European Neighbourhood Policy states - Algeria, Armenia, Azerbaijan, Belarus, Egypt, Georgia, Israel, Jordan, Lebanon, Libya, Moldova, Morocco, the Palestinian Authority, Syria, Tunisia and Ukraine.
}

My acknowledgements go to the two anonymous reviewers of this article, for their very helpful comments on the discussion and analysis presented in this article.

ISSN 1815-347X online - Barnes, P.M. (2008). 'Security of Energy Supply in the New Europe: A Role for the European Atomic Energy Community in the European Union's Neighbourhood Policy?', Journal of Contemporary European Research, Vol. 4, No. 2, pp. 107-129. 
access to the benefits of the internal market agreed between the EU and each state. The EU's positive leverage through this conditionality approach comes from the financial support ${ }^{2}$ and the other benefits including access to the internal market given on the basis of the extent to which the objectives of the plans are achieved.

An inevitable consequence of the deepening of the dialogue with the ENP states lying to the east is that the EU must engage in more structured dialogue with Russia which considers that the eastern states are states of its 'near abroad'. The development of a more assertive foreign policy by Russia during the leadership of Vladimir Putin had increased the difficulties encountered establishing this dialogue. As has the fact that some in Russia have gone so far as to declare that the EU has no legitimate interest in the ENP states. Emerson et al. (2007: 8) warn of the necessity of bearing this in mind in ENP developments and of the need for the EU to "...persuade Russia that its national interest lies in a co-operative rather than coercive approach to the common neighbourhood".

Driving the urgency of engaging in dialogue with the ENP states and Russia for the EU is the high level of import dependency for energy resources which the Member States have on energy supplies from Russia. The interdependency generated by the energy trade offers advantages to all parties but has resulted in a complex pattern of agreements, many of which are made on a bilateral basis between the parties. The result is a fragile triangular partnership in which two parties, the EU and Russia, are competing for influence over the same ENP states (see Figure 1). The former Soviet states of Eastern Europe are looking for a reason to turn to support from the EU to act as a counter-weight to pressure from Russia.

Figure 1: Europe's triangle of competing partners (the case of energy co-operation)

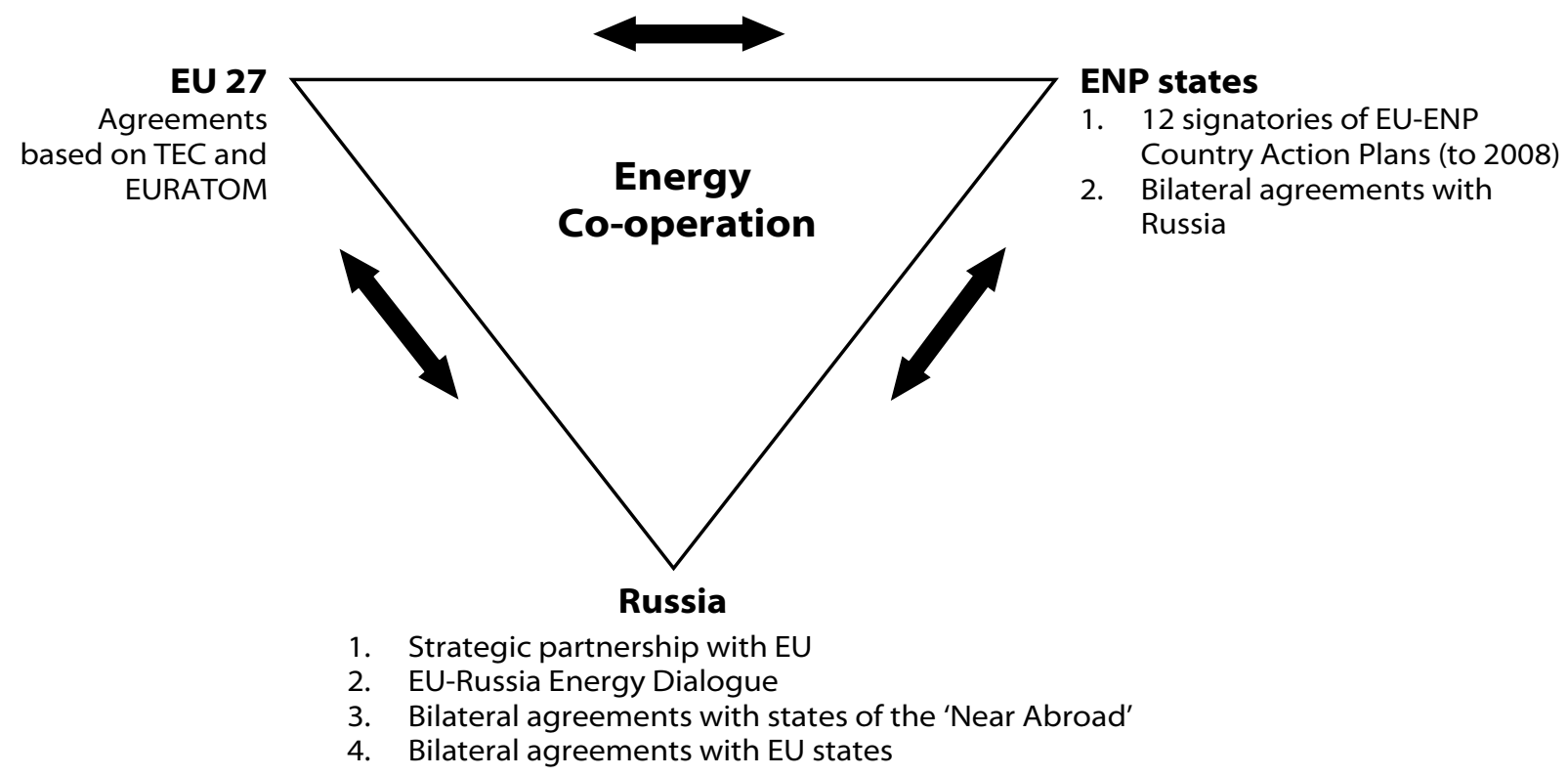

Many of these agreements in the field of energy co-operation focus on the trade in oil and natural gas but in this article attention is turned to development of co-operation on the production of electricity by nuclear technology. For the EU states the use of nuclear

\footnotetext{
${ }^{2}$ In 2007 the European Neighourhood Partnership Instrument (ENPI) replaced the TACIS and MEDA funds for the period 2007-2013 and with a budget of 11.2 billion euros, increasing the available funds for the ENP states by $32 \%$ from the previous budgetary period of 2000-2006. Of the EPNI Budget 494 million euros was allocated to projects in the Ukraine between 2007-2010 and 98.4 million euros to Armenia for 2007-2013.
} 
technology to generate electricity is a highly controversial issue and very different national policies have been adopted towards its use. All the EU states are signatories of the EURATOM Treaty which established the European Atomic Energy Community (EAEC) in 1957. In this article questions are posed about the role which the EAEC, and the competences established for it in the EURATOM Treaty, may play in the development of energy security in the wider Europe.

Energy security may be defined as the ability to secure access to secure and sustainable energy resources. The ideal would be for those resources to be indigenous and large-scale so that a country is able to respond to current demands and have confidence in its independence from other countries for future energy needs. But this is not possible in the interdependent world. As Gideon Rachman (2008) commented in an article in the Financial Times "calls for energy independence are all but universal". Energy security (i.e. the ability to access secure and sustainable energy resources) is now central to the foreign policies of the United States, the emerging Asian economies and the EU.

The launch of the Energy Policy for Europe in 2007 outlined the EU's strategy to access secure and sustainable energy resources, emphasising the importance to this objective of the development of a more coherent approach to external energy policy (CEC 2007a). European Commissioner for External Relations and European Neighbourhood Policy, Benita Ferrero-Waldner (2008), identified the required objectives of such a policy as:

...addressing our ability to maintain basic supplies and service, (including energy, (specifically) ...diversifying our sources of supply, our transit routes and our internal energy mix...addressing energy security in our political dialogues with all external partners; discussing and taking action to protect critical infrastructure and diversify supply routes and building on the memorandum of understanding we have already signed with countries like Azerbaijan, Egypt, Turkmenistan and Jordan (ENP states).

The analysis presented in this article demonstrates the ways in which the EURATOM Treaty offers an opportunity for the EU to act as a single entity, concluding agreements with Russia and the ENP states to achieve a number of objectives including some with regard to aspects of safety in the nuclear sector, accountability of nuclear materials to ensure they are not diverted to military usage, combating trafficking of nuclear materials and technology transfer and co-operation (CEC 2006b:17). ${ }^{3}$ In the absence of changes being made to its terms or legal status it is argued that the EURATOM Treaty strengthens the available policy instruments of energy dialogue and co-operation within the EU's Neighbourhood Policy. ${ }^{4}$

\section{Weaving a Web of Agreements}

The power of the EU to conclude agreements on energy co-operation is undermined by the high degree of fragmentation of instruments and objectives which characterises EU Energy Policy overall. National interests remain strong in the arena of energy policy measures and national governments jealously guard their competences as the appropriate bodies to determine their own national energy policy structures. Despite a number of developments during 2006 and 2007 (e.g. the emphasis on the international dimension given to European Energy Policy (CEC 2006a:4), inclusion of a clause on energy solidarity in the Lisbon Treaty) the impact of the fragmentation in the internal operation of Energy Policy remains and is an obstacle to establishing a more coherent External Energy Policy.

\footnotetext{
3 These were identified in 2006 by the European Commission (2006b:17) as a group of nuclear issues of common interest where increased multilateral action would enable the ENP states and the EU to respond to more effectively in the wider regional context. A commitment was also made to enhanced dialogue with ENP partners planning to use nuclear energy in the future.

${ }^{4}$ Two ENP states are currently users of nuclear electricity - Ukraine and Armenia as is Russia. New reactor development is planned in all three states. Ukraine is also one of the world's uranium mining countries. In the discussion which follows the abbreviation ENP2 will be used to refer to Ukraine and Armenia together.
} 
Amongst the legal and constitutional tools which the EU has in its portfolio of instruments to achieve energy security in the wider Europe is the EURATOM Treaty. The Treaty has remained substantively unchanged since it was adopted in 1957. It may be repealed or amended at any time. But this would require the unanimous vote of all the signatory states and the political willingness to undertake revision of the EURATOM Treaty does not currently appear to be evident amongst the EU's national governments. Despite much criticism of its longevity and outdated emphasis on support for a single industrial sector the EURATOM Treaty thus continues to retain a separate legal personality from that of the European Union Treaty.

The Treaty was more difficult to negotiate in 1956 than its proponents had anticipated because of differences in national nuclear energy policies that had already emerged (for detailed discussion see European Parliament 2002). Although the political and socioeconomic environments within which the nuclear sector is operating in 2008 have altered, national nuclear energy policies which are highly divergent remain in place. As the author of this article has argued elsewhere, recent opportunities to amend or repeal the treaty were not taken (Barnes 2007). This would suggest that it would be difficult to negotiate a treaty in which the signatories agreed to co-operation on the peaceful, civilian use of nuclear technology today for different reasons from those encountered in 1957, most specifically because of difficulties reconciling national nuclear energy policies. So the question of what value the EURATOM Treaty has in the development of the actions of the Neighbourhood Policy must be addressed.

The Neighbourhood Policy is based on the EU adopting a role as a normative foreign policy actor and exporting through its exercise of soft power instruments the norms of European integration. ${ }^{5}$ In the wider European region the norms of energy co-operation are seen as improved security of access to energy supply, enhancement of competition, environmental protection, increased energy efficiency and development of renewable energy resources. The main tool which the EU has at its disposal to achieve its energy policy commitments is the market liberalisation and the opportunities for the transfer of energy resources on integrated transmission systems. Increased connectivity between the energy markets of the EU, the ENP states and Russia and the development of infrastructures for transfer of energy (including electricity) are vital components of the co-operation. Electricity is a potentially tradeable commodity within the enlarged internal market being created as a result of the agreements with the ENP states. It is not possible to differentiate the generating source of electricity on an electricity transmission network. De facto the opening of the internal market for electricity has increased the need for co-operation in the nuclear sector with those ENP states which are generating nuclear electricity (Ukraine and Armenia) and with Russia.

Nuclear energy co-operation is also founded on the commitments made by the EAEC on behalf of the EU states, the EU's member states acting separately, Russia, and the ENP states also acting separately, to adhere to the safety principles of the International Atomic Energy Agency (IAEA) ${ }^{6}$. These commitments form the basis of the International Convention on Nuclear Safety. ${ }^{7} \quad$ The objective of this Convention is to legally bind the signatory states

\footnotetext{
5 Joseph S. Nye defines (2005) soft power as the ability to be able to get others to want what you want by coopting rather than coercing them. It relies on attractiveness of a country's culture, political ideals and policies and in large part arises from the values and norms which are held within a country. The attraction of these is what encourages others to acquiesce or imitate them.

${ }^{6}$ The IAEA is an independent international organization reporting to the General Assembly and the Security Council of the United Nations. It was established as an autonomous agency by the United Nations on $29^{\text {th }}$ July 1957, as the world's Atoms for Peace Organisation, IAEA Statute, Article 2. 'The Agency shall seek to accelerate and enlarge the contribution of atomic energy to peace, health and prosperity throughout the world. It shall ensure, so far as it is able, that assistance provided by it or at its request or under its supervision or control is not used in such a way as to further any military purpose'.

7 The International Convention on Nuclear Safety was adopted June 1994, opened for signatures on $20^{\text {th }}$ September 1994 and entered into force 24th October 1996. The EAEC acceded to the Convention in 1999. By 2007 the Convention's signatory states numbered 65, including all 31 states with operating nuclear power plants globally.
} 
producing nuclear electricity to maintain a high level of safety at the power plants. Reports on the implementation of the necessary measures are subject to peer review at meetings of the IAEA. As the EAEC is a signatory to the Convention the European Commission has the requisite competences to provide these reports on behalf of the EU. The issues addressed in the Convention include ensuring that there is no undue risk to the health and safety of the general public and site personnel from the operation of nuclear installations, including nuclear power plants, research reactors, parts of the nuclear fuel cycle and related infrastructure.

\section{EURATOM: An Appropriate Legal and Constitutional Basis for Action in the Wider European Region?}

The EAEC was established to provide the conditions for the development of nuclear energy in Europe by sharing the resources required (financial, materials, technical and expertise). Specifically it was to provide protection of the workers in the industry and the general public and to enable agreements to be developed with third parties and international organizations on issues relating to supply and peaceful use of the technology. Exclusive Community competence for action focused on eight main areas which were outlined in Article 2 EURATOM, with prominence being given to safety of the workers in the industry and the public in the areas surrounding the nuclear power plants. ${ }^{8}$

These limitations on the competences given to the EAEC, including the lack of competence for the safety of the nuclear installations themselves, were the result of the powerful national interests that had resulted in the development of differing national nuclear policies in the 1950s. Two factors played a role in the reluctance of the Member States of the EAEC during the negotiations of $1956 / 1957$ to open up the nuclear sector. One was the link between the use of nuclear technology for electricity generation and the evolving nuclear weapons technology. Both energy and military strategic competences were and continue to be considered by national governments as vital aspects of national security interests. At the same time strong national commercial interests were evolving in the electronuclear sector and the Treaty negotiations were constrained by concerns by the national industry (particularly that of France) that commercial information would have to be revealed in order to ensure enforceable nuclear safety regulations by the EAEC (European Parliament 2002).

Despite changes to the political and socio-economic environments in which the electronuclear industry is operating the EURATOM Treaty has remained an element of the acquis which all EU states must adopt on their accession to the EU. As such the Treaty encompasses a group of signatory states with national nuclear policies as diverse as that of Austria (anti-nuclear) and France, Finland, Lithuania and Bulgaria (supporting new reactor

${ }^{8}$ In order to perform its task, the Community shall, as provided in this Treaty:

a) promote research and ensure the dissemination of technical information;

b) establish uniform safety standards to protect the health of workers and of the general public and ensure that they are applied;

c) facilitate investment and ensure, particularly by encouraging ventures on the part of undertakings, the establishment of the basic installations necessary for the development of nuclear energy in the Community;

d) ensure that all users in the Community receive a regular and equitable supply of ores and nuclear fuels;

e) make certain, by appropriate supervision, that nuclear materials are not diverted to purposes other than those for which they are intended;

f) exercise the right of ownership conferred upon it with respect to special fissile materials;

g) ensure wide commercial outlets and access to the best technical facilities by the creation of a common market in specialised materials and equipment, by the free movement of capital for investment in the field of nuclear energy and by freedom of employment for specialists within the Community;

h) establish with other countries and international organizations such relations as will foster progress in the peaceful uses of nuclear energy.

(Article 2 EURATOM) 
developments) to present a unified approach when dealing with aspects of external nuclear energy policy (see Barnes 2006 and Foggatt 2007).

It may be that the seeming resilience and longevity of the Treaty is because it "...(is) a remarkable document that expresses the essential commitments of the parties in a flexible and forward-looking language" (CEC 2002a:7). ${ }^{9}$ It may be because it is a very specific Treaty supporting an area of energy generation which appeared, particularly in the late 1980s and 1990s following the Chernobyl disaster, to be no longer relevant in the energy debate. Alternatively, the longevity of the Treaty may result from the fact that those negotiating Treaty changes are often more concerned with reform of the institutional frameworks which support the operation of the EU as a whole rather than one specific aspect of energy policy. ${ }^{10}$ Particularly as such negotiations would relate to a technology as controversial and divisive within the EU as the nuclear energy technology. Irrespective of the explanation, the Treaty remains. As such it is an instrument which the EU has at its disposal to use to support the developments of the frameworks of action with the ENP states and Russia.

The utility of the Treaty has been demonstrated in the interpretation and application of its terms throughout the history of the EAEC. Measures have been developed to improve the safety standards for the industry, monitoring of the use of nuclear materials, commitment to nuclear weapons non-proliferation and research into new aspects of the nuclear technology for commercial use. All the EU's nuclear generating states use safety standards based on those of the IAEA and the Convention on Nuclear Safety. These are standards which have been developed on the basis of international experience in nuclear safety since the 1950s. Safety of the nuclear installations themselves remains a competence of the national authorities of the nuclear generating states of the EU.

The safety regimes in place at the nuclear installations have evolved in independent ways in the differing national contexts because this competence was not transferred to the EAEC. But, at the same time a non-binding acquis has been developed within the EU combining and harmonising national practices on safety. ${ }^{11}$ In addition to this harmonisation of national practices a number of legislative acts based on the legal framework of the EURATOM Treaty have been adopted all of which do have an indirect impact on installation safety (Barnes 2003). As a result by the beginning of the 2000s the European Commission confidently concluded that the EU has the most effective safety regime and system of control of nuclear materials in the world (CEC 2002d). A conclusion that appears to have been substantiated, by the close co-operation which has been achieved between the EAEC and the IAEA on the safeguarding of nuclear materials. ${ }^{12}$

In recognition of the growing urgency to address problems relating to nuclear decommissioning and safety of nuclear reactors, particularly in the light of enlargement to Central and Eastern European states (CEC 2002d) the European Commission proposals for a package for measures to address these concerns were put forward in 2003 (CEC 2003a) on the basis of the EURATOM Treaty. Despite amendments being made to the proposals (CEC 2004b) they remained un-adopted in 2008. But safety of the electronuclear industry sector

\footnotetext{
${ }^{9}$ In 2002 a High Level Expert Group was established to report on the effectiveness of the ESO as the terms of the EURATOM Treaty had not been revised since 1957. The findings of the Group were that the ESO should remain the focus of EU wide controls for both practical and legal reasons. "The EURATOM Treaty being a remarkable document that expresses the essential commitments of the parties in a flexible and forwardlooking language" (CEC 2002:7).

${ }^{10}$ My thanks to one of the anonymous reviewers of this article for reminding me of the realities of the negotiating process within the EU.

${ }^{11}$ Also supporting the development of the voluntary harmonisation of national practices is the work of the Western European Nuclear Regulators Association (WENRA) established in 1999 by the regulatory authorities of the EU and Switzerland to build a network of European states to determine a common approach to safety and develop an independent capability to examine nuclear safety in the applicant states of the EU. In 2008 the regulatory authorities of 17 European states were parties to this association.

12 Co-operation based originally on a Cooperation Agreement between the EAEC and the IAEA 75/780/EURATOM, OJ L 329, 23.12.1975 pp.28-29, strengthened in a joint statement by Commission President Barroso and Director-General of the IAEA Dr. El Baradei in May 2008, IP/08/719, Brussels 07.05.2008.
} 
has been identified as of high priority in the development of the EU's energy policy, both within the EU and in its relations with other states. At EU level the Heads of Government of the Member States have declared that the role of the EU should be "...to develop further, in conformity with Community law, the most advanced framework for nuclear energy in those Member States that choose nuclear power, meeting the highest standards of safety, security and non-proliferation as required by the EURATOM Treaty ..." (Brussels Council March 2007: para.32). And as "...nuclear power also raises important issues regarding waste and decommissioning so nuclear waste management and decommissioning should also be included in future Community work. The EU should also continue their efforts to ensure that such standards are observed internationally" (CEC 2007a:17).

Support for the development of nuclear industry in the EAEC was based on the EURATOM Treaty provision for funding for research and development of nuclear fission technology (Article 7 EURATOM). This support for the EURATOM research programmes has continued throughout the history of the EAEC, the most recent being included in the Seventh Framework Research and Technology Development programme (FP7) proposed by the European Commission 2007-213. Agreement on the budget for the EURATOM Research Programme 2007-2011 13 was difficult to achieve because of the divergent views of the national governments about further developments in nuclear fission technology. Eventually agreement was reached in the Council of Ministers on 24 July 2006 with the bulk of available funding being directed to new fusion technology developments and limited amounts for decommissioning of fission technology. ${ }^{14}$

Of the total budget for EURATOM research of 2.7 billion euros, 2.1 billion are to be allocated to fusion research and in particular the development of the International Thermonuclear Experimental Reactor (ITER) which is under the auspices of the IAEA. ${ }^{15}$ The agreement for the ITER development in Cadarache, France, was signed on 21 November 2006 and will include input from the EU27, represented by the EAEC, Russia, Japan, China, India, South Korea and the United States. The ITER development is regarded by many as having the potential to make a major contribution to sustainable and secure energy supplies in Europe. Critics such as Friends of the Earth (FoE) on the other hand point out that it is unlikely to be at the stage of commercial production before 2050 because of the difficulties of achieving and maintaining the high temperatures needed for the reaction to take place. In the view of FoE it will take too long and require a very large investment which could be used in the development of other energy technologies.

Further financial support for the evolving European nuclear industry came when a lending instrument was established in 1977 empowering the European Commission to issue EURATOM loans for the purpose of contributing to the costs of construction of nuclear power stations (Council Decision, 77/270 EURATOM). In the period between 1977 and 198790 new-build projects in Belgium, France, Italy, Germany and the UK were partially financed through this loan facility. However as concerns about the safety of the nuclear industry grew in the late 1980s following the Chernobyl disaster no applications were made for new projects by the nuclear states of the EU 12 and all loans had been repaid by 2000 .

\footnotetext{
${ }^{13}$ Although included in the FP7 the budgetary line for EURATOM actions remained separate and for a shorter period of time than other funding for research projects, but a facility was agreed to extend the EURATOM funding for an additional two years to ensure that the budgetary lines were synergous with one another.

${ }^{14}$ Nuclear fusion - is the process of fusing two hydrogen atoms to form a single atom of helium. One gram of the fuel produced can develop the same energy as 45 barrels of oil. However the process requires extremely high temperatures which it is not yet possible to achieve in a reactor.

15 The total funding package of the FP7 was more than 50 billion euros for the time period 2007-2013. The EURATOM Budget as a separate budgetary line included 2.7 billion euros for the period 2007-2011 with the possibility for an extension of funding to for the period to 2013. Energy technology research was identified as one of the co-operative themes in the overall budget with 2.3 billion euros allocated to new energy technology developments particularly renewable energies. A difference in funding that led environmentalists to express concern that the nuclear technologies were receiving unjustifiable levels of support which would divert attention from the development of renewable technologies.
} 
Although no loans were authorized from 1987 in 1994 the scope of the EURATOM lending facility was extended (Council Decision, 94/179 EURATOM). The Commission was authorized to contract EURATOM borrowings in order to finance improvements in safety and efficiency of non-EU member states - specifically targeting Former Soviet Union (FSU) states likely to be amongst the first to apply for membership of the EU, and also Ukraine. In particular:

...the Commission is empowered to contract borrowings the proceeds of which will be
allocated in the form of loans to finance projects to increase the safety and efficiency of the
nuclear power stations of the non-member states... (projects must relate)... to nuclear power
stations or installations in the nuclear fuel cycle which are in service, or under destruction or to
the dismantling of installations where modification cannot be justified in technical or
economic terms (CEC 2002c:2).

Using this facility EURATOM loans were provided for improvements to safety standards and/ or construction to the Bulgarian government (in 2000 for Kozlduy 5 and 6 reactor units, 12.5 million euros), Romania (in 2004 for Cernovoda 2, 223.5 million euros) and to Ukraine (in 2004 Khmelnitzky 2 and Rovno 4 units, 83 million euros) (2002c:18). ${ }^{16}$ Articles 41 - 44 EURATOM Treaty require notification to be made to the European Commission of any new reactor developments within the EU. A favourable opinion is then required from the Commission on the provisions made by the national governments of finance to meet de-commissioning costs and funds for the management of radioactive waste. By complying with these requirements in 2007 in preparation for the construction of a new reactor unit at the Belene site, the Bulgarian government became the first member state of the EU to be eligible for a EURATOM loan since 1987.

Criticisms of the EURATOM Treaty may be made on the grounds that developed as it was in the context of the highly regulated and subsidised energy sector of the 1950s it is based on an outmoded paradigm of state support for a sector of energy production. Svein Andersen in a study of the liberalization of the gas market points to the way in which the energy policy paradigm underpinning EU action has changed since the 1950s from a traditional model of energy developments by public bodies supported by long term state investment and subsidies to one of market functionality (Andersen 2000). There is still a considerable element of state involvement in the contemporary energy sector but the focus is now on the creation of liberalized power markets in which all modes of electricity generation should be competitive without state support. As the EU 27 is faced with the energy reality of increasing dependency on imported energy resources the primary tools which are available to respond to this challenge are those of the market.

Any subsidies given to energy developments may be seen in terms of unfair advantage for that particular technology over other aspects of the energy sector. The creation of the European internal market for energy requires an underpinning of a level-playing field for all electricity producers. Electricity, as a product from all generation sources, is a tradeable commodity which may be moved both within the integrated European energy market and as a commodity for export trade outside the EU. EU competition legislation applies to nuclear electricity as a commodity available for trade. Legislation to liberalize the EU's national markets in electricity and thus reduce prices for domestic, commercial and industrial users, based on the TEC, applies also to electronuclear production.

Here lies the problem for the EU in dealing with nuclear energy. The EURATOM Treaty provides a framework for collaborative action that includes support for high levels of state intervention to assist the development of nuclear energy technology. The economic viability of the electronuclear industry remains contested, as is the question of appropriateness in terms of offering state support for the use of technology which requires a high level of capital investment in the construction phases in an increasingly liberalised and privatised energy sector. From the viewpoint of the contemporary electronuclear industry itself

\footnotetext{
${ }^{16}$ At the time these loans were agreed with the Bulgarian and Romanian governments neither state was a member state of the EU.
} 
however it has been "...demonstrated that nuclear power does not, over the long term, require subsidy". (World Nuclear Association (WNA) 2005:10). A situation acknowledged by the European Commission "...if you would like to build a nuclear power station it is an investment-based decision without state aid. We are not in a situation where we should provide state aid for the nuclear industry..." (Piebalgs 2006). However in the view of the European Renewable Energy Federation and Greenpeace when they launched their challenge to the funding arrangements for the new reactor development at the Okiluoto site in Finland state aid in the form of export credits and loans at special rates to the companies involved are indeed examples of state subsidies to the nuclear sector (Greenpeace, Press Release, 26 September 2007). ${ }^{17}$

The creation of the European Atomic Energy Community was not a commitment by the national governments of the six signatory states to any form of co-operation on the military use of nuclear technology in 1957. The political realities of the 1950s Treaty negotiations were dominated by the reluctance of the national governments of the EU to proceed with strategic and military integration in a context other than the North Atlantic Treaty Organisation (NATO). The underlying political philosophy for the creation of the EAEC was a search for peaceful co-operation, not collaboration so that weapons of war could be developed. Not all the EU's Member States had developed or were intending to develop nuclear weapons capability in the 1950s. As it remains an element of the EU's acquis the EURATOM Treaty is one of two treaties which have an impact on the approach to nuclear non proliferation which is adopted by the EU 27 - the Nuclear Non-Proliferation Treaty (1 July 1968) (NPT) being the other. Both contain measures and statutes on safeguards of materials. All the NPT signatory states (those which are nuclear weapons states and those which have agreed to exclusively peaceful uses of the technology) have voluntary agreements and protocols with the IAEA for inspection to ensure that nuclear materials are not being diverted to military use. ${ }^{18}$

The EURATOM Treaty transferred competences to the EAEC to ensure that the fissile materials being used in the nuclear reactors of the EAEC were only being used for peaceful purposes. The EURATOM Safeguards Office (ESO) was established to ensure all EU states did not divert or acquire materials away from their intended and declared uses (Chapter VII EURATOM). (The ESO is now based under the supervision of the Commission (DG TREN) and is considered to have more robust mechanisms in place and a much clearer current role and mandate than the EURATOM Supply Agency (ESA). ${ }^{19}$ The EAEC is thus a party to the agreements which have facilitated the co-ordination of its role with that of the IAEA in the monitoring of the terms of the NPT within the EU. For some of the supporters of the EURATOM Treaty it is this competence which has created a "...firewall against proliferation of nuclear weapons, through the elements of ownership of fissile material and nuclear safeguards ... (which) was and is its main success (of the Treaty)" (Linkohr 2007).

\footnotetext{
17 Subsidies for the nuclear industry are also the subject of much controversy in the US which has 104 operating reactors and plans expected to be made for up to 27 new reactor developments in the next two years. (Economist September $6^{\text {th }}$ 2007) The US Energy Policy Act of 2005 (Pub L. 109-058) includes provisions for grants of up $\mathrm{t} \$ 2$ billion in insurance against regulatory delays and lawsuits for the first six reactors to receive licences and begin construction. It extends a law limiting a utility's liability to $\$ 10$ billion in the event of an accident and provides a tax credit of 1.8 cents per kWh for the first 6,000 MW generated by new plants. The Act also guarantees for an indeterminate amount of loans to fund new nuclear reactors and other types of power plant using 'innovative technology'.

${ }^{18}$ France and the UK of the 189 signatory states of the NPT are declared Nuclear Weapons States (the others being the USA, Russia and China). Some NATO countries, the EU Member States of Germany, the Netherlands, Belgium, Italy, Greece and the applicant state of Turkey, have forces which are trained to use US nuclear weapons. India, Pakistan and Israel are known to have nuclear weapons and have not signed the NPT and North Korea is now withdrawn.

19 The EU is highly dependent on imported uranium supplies and the European Supply Agency was established in 1960 as a procurement agency. It was concluded in 2002 that the Supply Agency exists, '...but is a mere shadow of what was intended.' European Parliament (2002:xiii) In 2006 the ESA had only 17 employees but as the price for uranium ore rises on the world market its future role may arguably increase.
} 


\section{Reluctance to Repeal the EURATOM Treaty}

Recent criticisms have been made that the EURATOM Treaty is "... an undemocratic, outdated alien in the world of the liberalized market" (Fouquet 2005). These criticisms are NOT based on the Treaty competence in managing and developing aspects of safety in the electronuclear industry, an aspect of nuclear energy policy which many policy makers and members of the general public feel should be subject to a stringent legislative framework. Rather they are made on the basis of the lack of involvement of the European Parliament 20 in the decision making process of the EAEC and the high level of state support for an aspect of the energy sector as the European energy market becomes more open to liberalization and deregulation. As one of the founding Treaties of the European Union the EURATOM Treaty was included in the list of Treaties to be reviewed as outlined in the Laeken Declaration, 2001 (Laeken Council, December 2001). Whilst several options, including repeal of the Treaty, were possible discussion of the EURATOM Treaty was limited within the context of the Convention's debates.

The main argument for this appeared to be that the Praesidium of the Convention regarded the Treaty as a distinct, complex and technical subject which it was not appropriate for the Convention to consider (Secretariat of the European Convention 2003). As a result the EURATOM Treaty was retained instead as a Protocol annexed to the Draft Constitutional Treaty (DCT). A declaration was however appended to the Constitutional Treaty, (signed by Germany, Ireland, Hungary, Austria and Sweden) noting that the Treaty had been unchanged since its adoption in 1957 and supporting an Intergovernmental Conference to review its terms as soon as possible (Declaration 44, DCT).

Failure by all the Member States of the EU to ratify the Constitutional Treaty created a difficult period of reflection and then negotiation on alternatives amongst the national governments which concluded with the introduction of a draft Reform Treaty ${ }^{21}$ by the German presidency in 2007, being ratified in 2008. At the same time during 2006 and 2007 the European Union engaged in a search for an Energy Strategy which would ensure that secure, competitive and sustainable energy for the EU. Commitments to energy solidarity and action to curb climate change were included in a more explicit manner in the Lisbon Treaty proposals than such commitments have been to date in the Treaties. The outcome of these debates was for the EURATOM Treaty to be maintained in a Protocol as proposed in the DCT, thus leaving its separate legal personality unaltered. The question of an early IGC to review the Treaty was not addressed by the Heads of Government meeting to sign the Reform Treaty in Lisbon.

Despite the commitments to energy solidarity the Lisbon Treaty confirms that the supranational competences with regard to the energy sector are still to be limited. Measures in the field of energy will be taken by the ordinary legislative procedures with qualified majority voting in the Council and co-decision in the European Parliament. This should not affect the rights of Member States to decide on the choice of energy resources and the structure of their national energy industries. Decisions which significantly affect a Member

\footnotetext{
20 The European Parliamentarians have argued for a stronger role in the areas covered by the EURATOM Treaty as "... (I)t can be plausibly argued that it is precisely in these areas...relating to safety that the public most feels the need for rigorous democratic scrutiny, control and accountability" (EP 2002:2). Support for increasing the EP's role in the EURATOM Treaty also came during the deliberations of the Convention on the Future of Europe. In the so-called 'Penelope paper' which was prepared a by task force led by Francois Lamoureux, Director General DG TREN proposals for changes to the EURATOM Treaty included support for the extension of Qualified Majority Voting and co-decision to nuclear energy policy. (CEC 2002e) The objective of the proposals intended to bring the EP into the decision-making process include the power to adopt laws, with the Council, on basic standards for nuclear safety. A view which has continued to be represented within DG TREN of the European Commission "... the first - and most important in many ways would be to give the EP a greater role rather than just a consultative one. Make more decisions, co-decisions with qualified majority voting for more issues" Official of DG TREN in correspondence with author, July 2005. ${ }^{21}$ Signed by the Heads of Government in October 2007 in Lisbon when it adopted the name of the city in which it was signed and has since come to be known as the Lisbon Treaty.
} 
State's energy choices and the general structure of national energy supply remain subject to unanimity vote. It would thus appear that the Lisbon Treaty is proposing little change to the decision-making process which underpins the development of energy policy and measures in the EU.

The manner in which the national governments of the EU have decided to continue to guard their rights to choose their national energy resources demonstrates how little room there is for bargaining and consensus building between the national governments about future nuclear energy policy development. At the Brussels Council in 2007 it was clearly stated that the Energy Policy for Europe will pursue three objectives, fully respecting the Member States' choice of energy mix and sovereignty over primary energy resources (Brussels Council, March 2007). In the EU some states are more heavily dependent on the sector than others, some states are in the process of developing new reactors, some are reconsidering new nuclear projects, whilst others with no-nuclear policies nevertheless import electricity from states which are nuclear electricity producers. As such agreement would be difficult to achieve on regulation of an energy resource and technology which is regarded as unsafe by many amongst the electorates of the EU's Member States. The EURATOM Treaty does provide a legal framework for action which might not be provided if the Treaty was subject to renegotiation for amendment or repeal. From a practical perspective the impact of failures to ensure safe operation of the industry in the geographical area of the EU and its neighbouring states could result in major environmental consequences including damage to human health and life. Politically it is unacceptable for the decisions made about one country's energy policy to carry with it the potential to significantly affect another country's environment or population.

As the search for a competitive, secure and sustainable energy policy intensifies not just in the EU but globally the importance of maintaining a diversified electricity sector is apparent and it is in that context that the nuclear energy option is gaining in support (WEC 2007). Richard Youngs (2007), in his analysis of the EU's external energy policy, highlights how firmly the EU's energy policy is grounded in the internal market and its effective operation. In the external dimension the approach to energy security is thus focused on spreading the internal market rules to the east and south of the EU. The objectives of some EU states (such as Bulgaria) and those of the ENP (Ukraine) are to participate in trade of electricity, irrespective of the technology by which it is produced. Therefore "...care should be taken to ensure that the development of trade does not in the medium term lead to the placing on the (Market) of electricity produced in nuclear power stations whose safety is not guaranteed..." (CEC 2002d:74). The presumption being that the EU would not wish to encourage the maintenance and longevity of nuclear reactors which are located in the wider European region and contributing to the integrated electricity market but are palpably unsafe and should be closed.

\section{The EURATOM Treaty: A New Role for an Old Instrument?}

The European Union is heavily dependent on imported supplies of the fossil fuels needed to meet its growing energy demand. Solidarity amongst the Member States on energy measures appears to offer the most effective way forward to meet the challenges the EU 27 faces, but the rhetoric of the national governments does not match their action and protection of national interests continues as a constraint to proposed strategies. In March 2006 the European Commission launched a debate about how the European Union was to achieve the competitive, sustainable and secure energy policy which is required for the future (CEC 2006a).

Whilst there is agreement within the EU that energy usage and its impact on climate change should lead to the development of low or if possible carbon free economies there is debate about the most effective mechanisms to achieve this goal. No technology used for electricity generation currently is carbon free. It would appear that the renewable technologies, which are less carbon producing than the fossil fuels, are not yet able to match the growing 
demand for energy. The use of the nuclear energy option in national energy policies is gaining support globally, ${ }^{22}$ not just in some European states (see Table 1, below).

Table 1: Reactors by Member and Candidate State (to summer 2007)

\begin{tabular}{|c|c|c|c|c|}
\hline & $\begin{array}{l}\% \text { of national } \\
\text { electricity } \\
\text { produced by } \\
\text { the nuclear } \\
\text { sector }\end{array}$ & $\begin{array}{l}\text { Number of } \\
\text { operable reactors }\end{array}$ & $\begin{array}{l}\text { Reactors under } \\
\text { construction }\end{array}$ & $\begin{array}{l}\text { Reactors } \\
\text { planned and } \\
\text { proposed }\end{array}$ \\
\hline Belgium & 55 & 7 & & \\
\hline UK & 19 & 23 & & \\
\hline Finland & 26 & 4 & 1 & \\
\hline France & 78 & 59 & & 2 \\
\hline Netherlands & 4 & 1 & & \\
\hline Spain & 23 & 9 & & \\
\hline Sweden & 52 & 10 & & \\
\hline Germany & 32 & 17 & & \\
\hline Czech Rep & 41 & 6 & & 2 \\
\hline Hungary & 34 & 4 & & \\
\hline Lithuania (1) & 72 & 1 & & $1^{*}$ \\
\hline Slovakia & 55 & 6 & & 2 \\
\hline Slovenia (2) & 39 & 1 & & \\
\hline Bulgaria & 44 & 4 & & 2 \\
\hline Romania & 8 & 1 & 1 & 3 \\
\hline Croatia & & (with Slovenia) & & \\
\hline Turkey (3) & & 0 & & $3 / 5$ \\
\hline $\begin{array}{l}\text { EU } 27+ \\
\text { candidates }\end{array}$ & & 152 & 2 & 11 \\
\hline World (4) & & 442 & 28 & 204 \\
\hline
\end{tabular}

Source: various European Commission and IAEA (cited in Barnes 2008).

\section{Notes}

(1) Lithuania, planned new nuclear power plant with Latvia, Estonia and Poland

(2) Croatia, no nuclear power plant of its own but Croatian national electricity company has co-ownership of plant at Krško in Slovenia

(3) Turkey, accession to the EU estimated by 2020

(4) 68 of the global total of planned reactors are in China

\footnotetext{
22 World Energy Council (2007:Introduction) 'To meet energy demand of all households worldwide, energy supplies must double by 2050' with policy makers being prepared to keep all options on the table. Energy Policy Scenarios to 2050 World Energy Council, November 2007, WEC website
} http://www.worldenergy.org/publications. 
Nuclear electricity requires high levels of capital investment to be made at the construction phase but once in operation has low marginal operating costs and an ability to run most economically at very high load factors thus meeting the demand for volume base-load electricity. The International Energy Agency (IEA) 2006 World Energy report concluded:

\begin{abstract}
...new nuclear power plants could produce electricity at a cost of less than 5 US cents per kWh if construction and operating risks are appropriately managed by the plant vendors and power companies. At this cost nuclear power would be cheaper than gas-base electricity...(but) more expensive that conventional coal-fired plants...(but) the breakeven cost of nuclear power would be lower when CO2 prices are taken into account (cited in CEC 2006c:12).
\end{abstract}

Within the EU inability to meet demand with alternative sources was a major factor in the decision of French and Finnish governments in the period 2005-2007 to commission new reactors. It has been the driving force behind the decision of the Lithuanian, Latvian, Estonian and Polish governments to enter into discussion for a joint project to build a new reactor at the Ignalina site in Lithuania. The favourable opinion of the European Commission for the construction of a new reactor at the Bulgarian Belene nuclear power plant in December 2007 was to meet demand following the de-commissioning of other Bulgarian reactors in preparation for accession. The debate about nuclear electricity has also been reopened in other EU states such as Germany, Italy and the UK. For the ENP2 states Ukraine meets $48 \%$ of its electricity needs from its nuclear reactors, Armenia $42 \%$ and these high levels of dependency make it difficult for these states to find alternatives. Both states have plans in place for new reactor construction to replace reactors which are being decommissioned.

The Energy Policy for Europe (CEC 2007a) contains an outline of plans which would achieve the aims of increasing the security of energy supply, ensuring the competitiveness of European economies and the availability of energy and at the same time promoting environmental sustainability and combating climate change. This Action Plan was accepted by the European Council and accompanied by some ambitious targets to achieve curbs in greenhouse gas emissions the European Council "...emphasizes that the EU is committed to transforming Europe into a highly energy-efficient and low greenhouse gas emitting economy" (CEC 2007a: Annex 1). Whilst the contribution nuclear electricity may make to the development of a low carbon economy is contested, the European Commission in presenting this strategy for future energy policy considered that nuclear power was the least carbon-producing energy source after offshore wind power and small-scale hydropower (CEC 2007a:18).

It is acknowledged in the EPE Action Plan that no single element of policy provides all the answers and that energy policy must be addressed by many different policy areas. As a consequence of the changing acceptance of the nuclear sector, its increased economic viability, continued safety concerns and developments of the EU's technological lead in this field certain conclusions were drawn in the EPE.

\begin{abstract}
Recalling that the EPE will fully respect Member States' choice of energy mix the European Council notes the Commission's assessment of the contribution of nuclear energy in meeting the growing concerns about safety of energy supply and $\mathrm{CO} 2$ emissions reductions while ensuring that nuclear safety and security are paramount in the decision-making process, confirms that it is for each and every Member State to decide whether to rely on nuclear energy and stresses that this has to be done while further improving nuclear safety and the management of radioactive waste.... (CEC 2007a: para. 11).
\end{abstract}

The EURATOM Treaty as an element of the EU's energy acquis which all states accept on their accession includes the statement that "...only joint effort undertaken without delay can offer the prospect of achievements commensurate with the creative capacities of their countries ..." (Treaty Preamble). This statement implies a commitment (which has not been repealed) to solidarity on aspects of developments relating to the nuclear sector. The EURATOM Treaty thus gives the EU the competence "...to develop further, in conformity with Community law, the most advanced framework for nuclear energy in those Member States that choose 
nuclear power, meeting the highest standards of safety, security and non-proliferation as required by the EURATOM Treaty..." (CEC 2007a: Annex 1).

The EU's safety regime is based on the 25 safety principles of the IAEA which are also the basis of the International Convention on Nuclear Safety. There is overlap but not duplication in the work of the IAEA and the European Commission on nuclear safety and safeguards on nuclear materials. The European Commission and the IAEA work in close collaboration on the development of these standards. In order to avoid duplication of effort within the EU the IAEA procedures are invoked to verify the EU's procedures but not to replace what the EU is already doing. This is in recognition of the fact that through the European Safeguards Agency the EU states have in place a more comprehensive and effectively monitored system in place than the IAEA is able to achieve.

Although the role of the European Court of Justice is limited in the competences awarded by the EURATOM treaty the legislative acts and measures which are in place have been supported by rulings of the European Court of Justice. In aspects of the EU's nuclear regulation (e.g. transport of waste) the implementation mechanisms of the TEC may be applied. In the IAEA's monitoring through inspection of nuclear power plants in non-EU countries the issues of non-compliance with safety standards are harder to determine. Extending the EU's safety regimes and competences to co-operation with Armenia and Ukraine through the ENP policy will thus bring positive benefits.

\section{The Value-added of the EURATOM Treaty in the European Neighbourhood}

The value-added of the EURATOM Treaty as an instrument to address problems of safety in the operation of the nuclear industry both within the EU and in states in the European neighbourhood was first demonstrated in the early 1990s. The catalyst for the EU to take action outside its borders on nuclear safety came from two interlinked events. The first was the catastrophic events at the Chernobyl nuclear power plant in the Ukraine in April 1986 and the second was the interest shown in accession to the EU by states of the former Soviet Union. ${ }^{23}$ The action taken then has produced the model of action to be used in the ENP2 Action Plans.

Despite incidents such as the melt down of part of the core of reactor unit 2 at the Three Mile Island (TMI) nuclear power plant in USA in $1979^{24}$ a spirit of complacency about the safe operation of Western Europe's reactors had developed by the 1980s. This complacency was shattered in 1986 by the devastation wrought by the explosion and fire in the Soviet designed reactors at the Chernobyl nuclear power plant. Fall-out from the Chernobyl explosion was detected across the whole EU including the UK and Scandinavia, where it remains a problem today. It demonstrated very clearly how dependent the states of Europe are on one another to deal appropriately with nuclear safety in the wider European region. Admittedly the reactors in Western Europe had been built to different designs from those of the Soviet designed technology used at Chernobyl, but the widespread nature of the devastation undermined levels of support and confidence in the nuclear industry overall. It caused a re-think in some Member States of the EU, for example in Italy where reactor developments had been pioneered in the early 1960s. In November 1987 the outcome of a referendum held in Italy was to halt all new reactor construction programmes and initiate a programme of de-commissioning of existing reactors from 1990. The Italian government

\footnotetext{
${ }^{23}$ Date of applications from the former Soviet States - Hungary 31 March 1994, Czech Rep. 17 January 1996, Poland 5 April 1994, Slovenia 10 June 1996, Romania 22 June 1995, Slovakia 27 June 1995, Cyprus 4 July 1990, Latvia 13 October 1995, Malta 16 July 1990 , Estonia 24 November 1995, Lithuania 8 December 1995, Bulgaria 14 December 1995.

${ }^{24}$ Whilst it was felt that the TMI incident had been contained within the power plant itself in 1979 it was nevertheless considered to be serious enough for 30,000 people living in the local area to be screened for the effects of radiation until 1997. The clean up of the damaged reactor took 12 years at a cost of US $\$ 973$ million.
} 
reversed this policy in May 2008 and announced the development of an action plan to resume nuclear reactor development within 5 years.

When meeting in Munich in 1992 the leaders of the G7 countries ${ }^{25}$ commissioned a study of nuclear safety at nuclear power installations in Central and Eastern Europe and the countries of the FSU because of the widespread concerns about the safety of Soviet design reactors. Particular attention was paid at the G7 summit to developing a programme of action which would include support for the enhancement of regulatory regimes for improvements of the operational safety of plants, alongside the closure or up-grading of those plants with the most serious problems. These proposals were accompanied by calls for funding from the World Bank and European Bank for Reconstruction and Development (EBRD) and the completion of the International Convention on Nuclear Safety (G7 Summit Communiqué, 1992).

The EU Heads of Government concluded that it was appropriate for the EU to take a lead role in the international efforts to ensure the safety of the Soviet design reactors because of the proximity of the states where these reactors were located. A Council Regulation published in July 1992 emphasised the importance of intensifying the harmonisation of the safety measures within the EU. At the same time a commitment was made to intensify co-operation with the states of Central and Eastern Europe and the Republics of the former Soviet Union in order to bring the levels of safety in their nuclear reactors up to those of the EU's states (Council Resolution OJ C 172, 8 July 1992). Following from this as the states of Central and Eastern Europe made their applications for membership of the EU the Commission was given the mandate, based on its EURATOM Treaty competences, to undertake careful monitoring and review of their Russian technology nuclear reactors.

The overall objective of the work undertaken by the European Commission was to bring the accession states to a level of nuclear safety compatible with that of the EU's Member States. Analysis was prepared by the European Commission and included in the initial evaluation of the applicant states which was presented to the European Council in 1997 (CEC 1997). By the Cologne Summit of June 1999 a two-pronged approach to dealing with the safety at the Soviet design reactors had been developed by the European Commission. Firstly remedial short term action was to be undertaken at the reactors with the most serious problems and secondly the longer term safety considerations would result in closure of the unsafe reactors, modernisation of others and a commitment to a search for alternatives to nuclear generated electricity.

For the new Member States the reactor closures were deeply controversial. There is a high dependency on nuclear electricity in the new Member States as a domestic source of energy which will reduce their reliance on imports of Russian energy resources and its attempts as a result to retain influence in these states. However closure programmes have been carried out, supported by EU funding and new reactor developments are planned (for example in 2006 the governments of Latvia, Estonia, Lithuania and Poland signed an agreement for the construction of a new reactor at the Ignalina power plant, replacing a unit closed in preparation for EU accession) and others proceeding to construction.

The mandate given to the European Commission in the EURATOM Treaty to work in this field provided the basis of a coherent approach from the EU's Member States. The European Commission officials were brought into direct collaboration with the nuclear authorities of the accession states in order to ensure that appropriate regulatory authorities were established. This was before the states (Hungary, Slovakia, the Czech Republic, Bulgaria, Romania, Slovenia, Lithuania) using nuclear electricity had acceded to the EU. Agreements

\footnotetext{
${ }^{25} \mathrm{G} 7$ Informal grouping of leaders of Canada, France, Germany, Italy, Japan, UK, USA and the EU represented under current institutional structures by the President of the European Commission and the Head of Government of the Member State holding the rotating presidency at the time of the summit meeting. When the Russian Federation began to participate at these summits in 1998 the group assumed the title G8.
} 
on funding, including access to the EURATOM loan facility, from the European Union to support the closure and upgrading of reactors in the accession states were also initiated. It is this approach of technical assistance and financial support which has been adopted within the ENP framework of energy co-operation for the EU and the ENP2.

Financial support comes in the form of loans and grants. In 1991 the TACIS Nuclear Safety Programme ${ }^{26}$ was introduced with a total budget of 721 million euros (including 100 million for the Chernobyl shelter fund) and PHARE $^{27}$ funding of 192 million euros for the same period. As a result 950 projects were financed, 300 under PHARE, 650 under TACIS (CEC 2006c). In 2007 this funding was replaced by the Instrument for Nuclear Co-operation (INSC) with provisions to finance nuclear safety co-operation in the ENP2. ${ }^{28}$ The need for available funds for future reactor developments upgrades and modernisation of existing plants and de-commissioning of ageing reactors within the EU's Central and Eastern European States, the ENP2 states and Russia, however remains.

EURATOM loans (see above) are not disbursed from the EU's budgetary funds but are funded on the financial market. There is no subsidy from the Commission or the EAEC associated with EURATOM loans. But they are the only international financial instrument providing unrestricted long term funds for nuclear projects. EURATOM loans can only finance up to $50 \%$ of the investments needed, and therefore require involvement of complementary financial sources, such as:

- In EU member states: internal cash flow of the operator, financial market, banks, European Investment Bank (EIB).

- In non-member states: the state concerned, the EBRD (only available for closure of reactors), internal cash-flow of the operator, financial market, banks, export credit agencies.

The period of highest levels of financing for nuclear electricity generation by the EIB was between the 1960s and 1980s when 6.6 billion euros was lent for investments for nuclear power stations, experimental facilities and facilities relating to the nuclear fuel cycle in France, Germany, Belgium, the UK and Italy. In a similar fashion to the fall in applications for funding through EURATOM loans during the 1990s and early 2000s few requests were made to the EIB for financing of nuclear electricity projects. In 2007 the EIB reviewed its policy with regard to energy related projects in the light of the adoption of the EPE. The EIB's Corporate Operational Plan for 2007-2009 included five energy related priorities - renewable energy; energy efficiency; research development and innovation in energy; security and diversification of internal supply (including the trans-European networks); energy security and economic development in neighbourhood and partner countries (EIB 2007). As nuclear sector projects raise very specific issues of safety and requirements for de-commissioning funding the EIB require notification to the Commission under the terms of Article 41 EURATOM as an essential pre-requisite before a loan is authorised. The EIB also carries out economic, technical, environmental and financial assessments of all projects and ensures that they are fully consistent with EU and national law and policies.

In December 2007 the European Commission gave the required favourable opinion to the new nuclear power plant at Belene, Bulgaria (IP/07/1874, Brussels 6 December 2007) in

\footnotetext{
${ }^{26}$ TACIS is the instrument established in 1991 to provide financed technical assistance to states in Eastern Europe and Central Asia, including Armenia, Russia and Ukraine. It was initiated as a 'stand-alone' programme but has become an instrument of the more strategic approach being developed by the EU towards these states.

27 PHARE (Pologne, Hongrie, Assistance à la Reconstruction Économique) set up in July 1989, initially to support the transition of Poland and Hungary to democracy and market economies and then widened to encompass all the Central and Eastern European states.

28 The INSC was established by Council Regulation EURATOM 300/2007 on nuclear safety co-operation, February $19^{\text {th }} 2007$, published in the OJ L 22.03.2007, 81/1, with a budget allocated of 524 million euros for the period 2007-2013. It replaced the TACIS Nuclear Safety Programme.
} 
accordance with articles 41-44 EURATOM notification of new developments. The favourable opinion followed discussions between the European Commission and the Bulgarian government about financing of future de-commissioning at the proposed reactor and safety at the installation. It is estimated that a EURATOM loan facility of 300 million euros will be authorised in addition to financing from the EIB. (European Atomic Forum 2008) The first of the two units at the new plant is expected to begin operation in 2011 and the second in 2013. The new power plant is intended to replace lost capacity from the closure of reactor units at the Kozloduy plant, which was a condition of Bulgaria's accession to the EU. In addition the objective of the new reactor development is also to enable Bulgaria to become an electricity exporting state.

A number of controversies had surrounded the proposal for the new Belene reactor. The project is an initiative of the Natsionalna Elektricheska Kompania of Bulgaria (which will hold $51 \%$ stake in the investment) and is based on a design developed by Atomstroyexport JSC of Russia (a company in which the state owned Gazprom has an interest). Atomstroyexport will act as the main contractor with Areva NP (France) and Siemens (Germany) as the main subcontractors. Concerns were raised that this would in essence be Soviet designed technology and would not meet the standards of safety required within the EU. However the reactors are to be Russian design but their operational systems will be supplied by Areva and Siemens. In addition, although a single regulatory safety design standard does not exist for the EU as a whole, the project met the European Utility Requirements for Light Water Reactors ${ }^{29}$ (which is also the basis for the development at the Olkiluoto 3 nuclear reactor unit in Finland).

The agreement on this contract, which includes Russian input, is a demonstration of the continued influence of Russia in Bulgaria, now an EU state. It was one of a package of energy contracts agreed between Russia and Bulgaria in January 2008 including co-operation on the construction of the South Stream gas pipeline which is valued at more than 10 billion euros. The conclusion of this package of energy contracts between Russia and Bulgaria demonstrates two realities of the energy challenges being faced within the wider European region. Firstly the levels of energy interdependency which exists and the interaction between the energy utilities which are involved in the sector and secondly how difficult it is for the EU to establish a common external energy policy when member states engage in bilateral agreements with a third party.

\section{Co-operation with Russia in the European Neighbourhood}

The co-operative approach to dealing with nuclear safety issues with Russia and with Russian support to deal with nuclear safety issues in the wider European region has evolved since the mid-1990s. This is evidenced in the meetings of the G8 states and since 2000 in the EU-Russia Energy Dialogue. At the G8 Summit held in Moscow in April 1996 Russia joined the G7 States in publishing a declaration on Nuclear Safety and Security. The emphasis in this declaration was on international collaborative action to promote a high level of nuclear safety worldwide. It provided the grounding for increased collaboration and co-operation on nuclear related issues between the EU, the other states of the wider European region, for which accession is not an option in the short term but a longer term perspective, and also Russia.

The G8 Summit in Kananaskis, Canada (2002) agreed to establish a G8 Nuclear Safety and Security Group which reported back at the 2007 Summit in Heiligendamm, Germany. The

\footnotetext{
${ }^{29}$ EUR European Utility Requirements for Light Water Reactors - this is a common set of requirements agreed by the major European utilities for Light Water reactors at nuclear power plants. They were developed as a result of a project begun in 1991 to promote the harmonisation of the safety approaches, equipment specification and standards and the information needed for the assessment of safety in LWRs. Amongst the utilities which are parties to the EUR agreements are British Fuel (UK), EdF (France) and Rosenergoatom (Russia).
} 
objective of the report was to "...develop a common understanding of internationally acceptable safety and security levels in the fields of nuclear installations, radioactive sources, decommissioning, radioactive waste and spent fuel management facilities in order to benchmark ...national practices". Support for the Ukrainian government to convert the damaged reactor unit at Chernobyl to a safe condition and for the Armenian government's closure and de-commissioning of the Medzamor nuclear power plant were highlighted in the report. The EURATOM Treaty provides the legal and constitutional framework for the EU states as a group in the implementation of measures relating to these commitments.

The main tool of foreign policy which the EU has at its disposal is the prospect of accession. Requirements to close or upgrade reactors in the accession states were included in conditions for membership introduced to exert influence on states prior to their accession in 2004/7. The interdependencies between the EU 27 and the ENP countries in the field of energy demonstrate the desirability for the EU of establishing a common legal framework on energy with these states. In December 2006 the European Commission concluded that the ENP policy had achieved good results and become the established vehicle for co-operation across a wide range of issues but made proposals for more effective action (CEC 2006b:8). In presenting proposals for increasing the effectiveness of the ENP the European Commission reiterated the commitment to largely bilateral agreements in order to reflect the specific needs of the neighbouring states. But a number of cross-cutting themes were also identified with energy co-operation as being one of the most important where the EU and ENP states share common interests and which could be usefully addressed in a multilateral context. Indeed the interdependencies which exist in the wider European region and with Russia on aspects of energy co-operation raise this as an issue of importance in all agreements made between the triangle of partners - EU 27, ENP states and Russia.

Of the two current nuclear generating states of the ENP the Ukraine is the most significant strategically. It occupies a geographical location between Poland, Romania and Moldova in the west, Belarus in the north and Russia in the east. As a result of this location it is in the eastern region of Ukraine that Russian influence is most evident. Russia has not been slow to use energy as a weapon to maintain its influence in Ukraine (demonstrated in January 2006 when Gazprom. the state controlled Russian company, cut gas supplies to Ukraine, causing a reduction in gas supplies in some EU states and again in January 2008 when similar action was threatened). Co-operation in the area of nuclear safety between the EU and Ukraine began in the early 1990s and by 1998304.3 million euros had been given through the EU's TACIS programme for nuclear safety, funds for the Chernobyl Shelter Fund and the Ukrainian G7 Action Plan. The Chernobyl Shelter Fund was established in 1997 to implement the Shelter Implementation Plan and to restore the damaged unit 4 at the Chernobyl nuclear power plant to an environmentally safe status. The total cost of this Plan is \$US 1 billion and overall the EU has been the largest contributor to the Fund. In addition EURATOM loans were also provided to Ukraine for upgrading and modernising reactor units at the Khmelnitskiy and Rovno nuclear power plants.

In October 2005 the European Union signed the Energy Community South-East Europe Treaty (ECSEE) with a number of Balkan states which came into force on 1 July 2006. Ukraine has observer status to the Energy Community but with the expectation of full membership in the Treaty in 2008. The primary objective of the Energy Community is to establish a single regulatory framework for trading energy across south-east Europe and the EU on the same terms. In order to do this it entails the signatory states adopting the acquis of the EU in the fields of energy (including the EURATOM Treaty), environment and competition. If Ukraine accedes to the ECSEE Treaty then the co-operation on nuclear safety will have a clear and firm legal basis.

A Memorandum of Understanding (MoU) on co-operation in the field of energy between the EU and Ukraine was signed during the EU-Ukraine summit in Kiev in December 2005. It formed the basis of the European Neighbourhood and Partnership Instrument between the $\mathrm{EU}$ and the Ukraine on energy co-operation. Two of the four identified areas of energy co- 
operation were nuclear safety of the operating Ukrainian nuclear power plants (subject to the competences discussed in this article) and the integration of the electricity market (subject to the terms of the TEC). Included in the MoU was an agreement for a safety evaluation in the Ukrainian nuclear reactors to be undertaken by the end of 2006. The MoU with Ukraine shows the relevance of the EURATOM Treaty to energy co-operation between Ukraine and the EU as it is under its terms that co-operation on nuclear safety, control of nuclear fusion, controls on trade in nuclear materials ${ }^{30}$ and fuel cycle services, prevention of illicit trafficking of nuclear materials, pursuit of nuclear research and technology development have been included in the agreement.

For Armenia, where the prospect of EU accession is an ambition but a more distant prospect than for Ukraine, participation in the ENP is a mechanism by which the regional isolation of the state and lack of economic development may be addressed. The Armenian average per capita GDP was only \$US 1,523 in 2005; considerable less than that of the EU 27 which equalled $\$$ US 32,900 in 2007. Tensions remain within the Southern Caucasus over the status of the region of Nagorno-Karabakh and settlement of Armenian-Turkish relations over the recognition of the Armenian genocide during World War I. As a result of these tensions the borders of Armenia with Azerbaijan and Turkey have remained closed and there has been a consequent impact on the Armenian economy. In the early 1990s war broke out between Armenia and Azerbaijan over the status of the Nagorno-Karabakh region. Although there has been a cease-fire since 1994 security in the region is an issue of grave concern for both Armenia and the EU.

A major focus in the EU-Armenia ENP Action Plan is co-operation on a peaceful resolution to the status of Nagorno-Karabakh in line with the strategic objectives of the EU's Security Strategy (CEC 2003c). The prospect of accession by Turkey to the EU has increased the tensions between Armenia and Turkey over the recognition of the Armenian genocide. Although it is not an official EU policy, many states of the EU have supported the arguments of Armenia that events in the region during World War I which led to the death of 1.5 million Armenians through Turkish actions should be recognised as a case of genocide. This is not a view accepted by Turkey.

Of the three states of the Southern Caucasus Armenia has the closest links to Russia in the energy sector. There is a high level of dependency on imported supplies of energy from Russia and vulnerability in particular to gas pricing disputes. Armenian government plans to diversify its energy sector to overcome the insecurity this action brings to the Armenian economy have been delayed by continued Russian influence and involvement in the energy sector. This in turn has led to increased levels of support for developments in energy cooperation under the umbrella of ENP action from the Armenian government. However there appears to be an impasse currently over the closure of the Medzamor nuclear power plant which involves the three parties - Armenia, the EU and Russia.

A major element of the EU-Armenia ENP plan is co-operation to close the Medzamor Nuclear Power Plant. This is a first generation Soviet designed nuclear power plant built in an area of seismic activity. It was identified as a dangerous nuclear power plant in the 1990s and became the subject of international action (see above on the Nuclear Safety and Security Group report at the 2007 G8 Summit in Heiligendamm). However as the plant provides 42\% of Armenia's electricity the Armenia government has pointed out to the EU that "...energy capacities must take account of the future expected needs of the Armenia, the need to strengthen energy security and the need to offset the closure of the Medzamor plant" (CEC 2005:2).

Bilateral dialogue on the Medzamor plant has been part of EU-Armenia co-operation since the early 2000s. In 2001 the EU offered to organise a conference of parties to create a fund to finance alternative energy capacity in Armenia, offering to provide 100 million euros of

\footnotetext{
${ }^{30}$ An issue which has gained in importance as supplies of uranium have become more expensive (the price of uranium ore had trebled on the world markets in 2007) and Ukraine is a supplier of uranium.
} 
assistance if a date could be agreed on closure of Medzamor. The EU view continues to be that the plant cannot be upgraded to internationally recognized standards at a reasonable cost and provides support for nuclear safety assistance at the plant. The Armenian government view is that closure of the plant will proceed before 2016 if an alternative source of electricity can be found. However as this commitment is associated with a plan to build a new reactor at the same plant, which will not only provide domestic electricity but enable export of electricity to take place, the concerns raised by the EU about safety of the new reactor because of its location in a zone of seismic activity remain. The Medzamor Plant is owned by the Armenian Ministry for Energy but is financially managed as the result of a debt settlement agreement for unpaid deliveries of nuclear fuels by Russia's United Energy Systems, an arrangement which is due to finish in 2008. But it is unlikely that the Armenian government will be able to proceed on the new reactor development without further involvement of Russian capital.

Russia is continuing to use the weapon of energy in its relationship with Armenia in other projects e.g. the investment of 250 million euros in 2006 by Russia in the construction of the Thermo Power Plant $V$ on the Hadrzan River. Instead of transferring capital for this investment gas tariffs will be maintained at a level of 55 euros instead of 110 euros as with other Russian trading partners. Armenia is almost completely dependent on imported energy. It does not have any coal production, oil or gas fields. The only source of domestic primary energy - electricity - comes from the thermo power plants of the Hadrzan River or the Medzamor nuclear power plant. For a state such as Armenia where the per capita GDP is one of the lowest in Europe and which is highly dependent on imported energy the attraction of such an arrangement is clear and maintains the close relationship which the state has with Russia. This is despite the fact that almost $40 \%$ of Armenia's export trade and $30 \%$ of its import trade is with the European Union.

Furthermore the gas transmission and distribution system of Armenia is owned and operated by Armrosgazprom which is a joint venture of the Russian owned Gazprom and Itera utilities and the Armenian state which has a $45 \%$ holding. The Armenian electricity distribution network is privatised with a British company Midland Resources Holding being the major shareholder. Of the generation plants $60 \%$ have been transferred into private ownership or Russian ownership to offset government debts (Energy Charter Secretariat 2004:11). As a result of the high dependence on imported energy and desire of the Armenian government to secure supply from diversified energy sources an important element of Armenian energy policy is to liberalise the electricity market and integrate into regional markets. Integration into the EU energy market through the ENP action plans provides an important counter-balance to the influence Russia is able to exert.

\section{Conclusion}

As a result of the energy interdependencies in the region there are arguments that cooperation should be enhanced by all parties the EU 27, the ENP states and Russia. However Javier Solana has warned that in the energy sector:

\footnotetext{
...there is a justified concern across Europe about Russia seeming more interested in investing in future leverage than in future production. Contrast Gazprom's spending spree abroad with the lack of investment and waste at home...(Furthermore) It is up to us to avoid the kind of fragmented bilateral negotiations which leave us all worse off. A more united and comprehensive approach would enhance our bargaining position (Solana 2008).
}

This is recognition that, unlike Russia, the EU is not a major source of energy, but rather is reliant on Russia as a mainstay of its own energy imports. So what leverage can the EU bring to bear on the neighbouring states if it does not award the prize of accession in the short term? 
The European Union has developed a new mechanism to extend its influence within the wider European region. The frameworks created in the context of the European Neighbourhood Policy which was launched in 2003 marked a different approach from the EU to co-operation with states on the eastern and southern borders. The purpose was to deepen the co-operation between the EU and these states to enhance stability and security in the wider European region with states which may or may not have the ambition to accede to the $\mathrm{EU}$ in the future. At the same time the ENP is not a mechanism to undermine that ambition. In the arena of energy co-operation the ENP utilises the main instrument of EU Energy Policy - that of access and integration to the energy market. In the arena of nuclear energy cooperation the instrument being utilised for joint action by the EU 27 is the EURATOM Treaty. The EURATOM Treaty has remained substantively unchanged throughout the history of the EU. It provides the competences for the EU to respond to co-operation on safe operation of nuclear reactors, safeguards on the management of nuclear materials to ensure their use for peaceful and not military purposes and safe management of waste in the wider European Region.

In the wider European region the EU and Russia are competing for influence in the ENP states but have differing approaches and tools. The high levels of energy interdependencies of all parties in this triangular partnership would suggest that there are advantages for all in maintaining a co-operative approach to one another in the European region. This requires two considerations to be taken into account by the EU. The first is the need to balance its response to the needs of the regional co-operation with an awareness of the pressures on Russia to maintain its influence in the region. The second consideration is that as the EU does not yet have a coherent external energy policy urgent action must be taken in order to develop one.

The efficacy of the EURATOM Treaty as an external policy instrument to deal with issues of nuclear safety and safeguards of nuclear materials was demonstrated during the 1990s and early 2000s in states in Central and Eastern Europe. Although the goal for these states was accession to the EU the co-operative approach supported by financial aid and technical assistance to upgrade and modernise reactors proved the success of the use of the competences of the Treaty and the expertise of the European Commission to effect changes in states before they became members of the EU. As an external foreign policy tool the EURATOM Treaty provides the EU with an opportunity to bring pressure to bear on the nuclear generating states of its Neighbourhood - Armenia and Ukraine - to deal with issues of nuclear safety and the safeguard of nuclear materials. It is for this reason that this article has argued that there is a role for the EAEC and its founding Treaty in the European Neighbourhood Policy.

\section{References}

Andersen, S.S. (2000). European Integration and the changing paradigm of energy policy, Arena Working Papers, WP 13/2000, available at: http://www.arena.uio.no/publications/working-papers2000/papers/wp00 13.htm, last accessed 19 June 2008.

Barnes, P.M. (2003). 'Nuclear safety for nuclear electricity - the search for a solid legal basis for nuclear safety in a enlarged EU', Managerial Law, 45 (5/6), pp. 115-139.

Barnes, P.M. (2006). 'The nuclear industry - a particular challenge to democracy in Europe?', Managerial Law, 48 (4), pp. 400-429.

Barnes, P.M. (2007). 'The Future of EURATOM', in N. Neuwhal and S. Haack (eds.), Unresolved Issues of the European Constitution. Montreal: Les Editions Themis Inc.

Barnes, P.M. (forthcoming 2008). 'The Resurrection of the EURATOM Treaty - contributing to the legal and constitutional framework for secure, competitive and sustainable energy in Europe', in T. Etty (ed.), Yearbook of European Environmental Law. Oxford: Oxford University Press. 
Commission of the European Communities [CEC] (1997). Agenda 2000: for a stronger and wider Europe, Volume III.

CEC (2000). Nuclear Safety in the newly independent states and Central and Eastern Europe COM (493) final, Brussels.

CEC (2002a). 'High Level Expert Group', Review of the EURATOM Safeguards Office, (report), Brussels.

CEC (2002b). 'Final report on the Green Paper', Towards a European strategy for the security of energy supply COM (2002) 321 final, Brussels.

CEC (2002c). Proposal for a council decision amending Decision 77/721 ...empowering the Commission to issue EURATOM loan for the purpose of contributing to the financing of power stations. COM (2002) 457 final, Brussels.

CEC (2002d). Nuclear Safety in the European Union. COM (2002) 605, Brussels.

CEC (2002e). 'Proposal for an additional act to the Constitution, No2 - Peaceful use of Atomic Energy - the 'Penelope Paper'. Commission Task Force DG TREN, December, Brussels.

CEC (2003a). Proposal for Council Directives (EURATOM) setting out basic obligations and general principles on the safety of nuclear installations [And] On management of spent nuclear fuel and radioactive waste, COM (2003), 32 final. 31.01.2003

CEC (2003b). On wider Europe, a New Framework for Relations with our Eastern and Southern Neighbours, COM (2003) 104 final, Brussels.

CEC (2003c). A Secure Europe in a Better World - European Security Strategy, December 12.12.2003, Brussels.

CEC (2004a). European Neighbourhood Policy - Strategy Paper, COM (2004) 373 final, Brussels.

CEC (2004b). Amended proposal for Council directive (EURATOM) laying down basic obligations and general principles on the safety of nuclear installations [And] Amended proposal for a Council Directive (EURATOM) on the safe management of the spent nuclear fuel and radioactive waste, COM (2004) 526 final. 23.09.2004

CEC (2005). Commission staff working paper - Annex to ENP Country report on Armenia SEC (2005) 285/3, Brussels.

CEC (2006a). Green Paper A European Energy Strategy for Sustainable, Competitive and Secure Energy, COM (2006) 105 Brussels.

CEC (2006b). Communication on strengthening the European Neighbourhood Policy, COM (2006) 726 final, Brussels.

CEC (2006c). Communication from the Commission to the Council and the European Parliament, Nuclear Illustrative Programme, COM (2006) yyy final, Brussels.

CEC (2007a). An Energy Policy for Europe, COM (2007) 1 final, Brussels.

CEC (2007b). Fifty Years of the EURATOM Treaty, COM (2007), 124 final, Brussels

Emerson, M, Noutcheva, G. and Popescu, N. (2007). European Neighbourhood Policy Two Years On - time indeed for an 'ENP Plus' CEPS Policy Brief No 126/March 2007, available at: http://shop.ceps.eu/downfree.php?item id=1479, last accessed 19 June 2008.

Energy Charter Secretariat (2004). Armenia, country report on Investment Climate and Market Structure.

European Atomic Forum (2008). New Build and Phase-Out policies in Europe. Brussels: FORATOM.

European Council (2001). European Council Presidency Conclusions, Laeken 14-15 December 2001.

European Council (2007). European Council Presidency Conclusions, Brussels, 8-9 March 2007.

European Investment Bank (2007). EIB and Financing of nuclear energy Briefing note, Luxemburg.

European Parliament (2002). The EP and the EURATOM Treaty: past, present and future, Energy and Research Paper ENER 114, EP.

Foggatt, A. (2007). 'Nuclear Power - the European Dimension', in D. Elliott (ed.), Nuclear or not? Does Nuclear Power Have a Place in a Sustainable Energy Future? Basingstoke: Palgrave Macmillan.

Fouquet, D. (2005). The Legal Perspective: the EURATOM Treaty and the new Constitution, presentation to Energy Intelligence for Europe Conference, 23 September 2005, Copenhagen, available at: 
http://www.energyintelligenceforeurope.dk/Documents/Fouquet20050923b.pdf, last accessed 19 June 2008.

G7 (1992). G7 Summit Communique, Munich July 6-8 1992 on the Safety of Nuclear Power Plants in the newly Independent States of the Former Soviet Union and in Central and Eastern Europe.

Linkohr, R. (2007). Assessing EURATOM - 50 years of European nuclear policy, presentation given at Public Hearing, European Parliament Committee on Industry, Research and Energy, European Parliament, Brussels, 1 February 2007.

NEA/IEA (2005). Projected costs of generating electricity - 2005 update, Joint report. Paris: OECD.

Nye, J.S. Jr. (2005). Soft Power - the means to success in world politics. Oxford: Oxford University Press.

Piebalgs, A. (2006). House of Lords Select Committee on the EU, sub-committee D, uncorrected evidence on the management of radioactive waste and the safety of nuclear installations, question 456, given on Monday 20 March 2006, Brussels.

Rachman, G. (2008). 'The oily truth about America's foreign policy', Financial Times, 13 May 2008.

Secretariat of the European Convention (2003). Suggested Approach for the EURATOM Treaty, CONV 621/03 Brussels, 14 March.

World Energy Council (2007). Energy Policy Scenarios to 2050 World Energy Council, November, available at:

http://www.worldenergy.org/documents/scenarios study online 1.pdf, last accessed 19 June 2008.

World Nuclear Association [WNA] (2005). The New Economics of Nuclear Power. London: WNA.

Youngs, R. (2007). Europe's External Energy Policy: between geopolitics and the Market, CEPS Working document no 278 , available at:

http://shop.ceps.be/downfree.php?item id=1560, last accessed 19 June 2008 . 